\title{
Quantitative immunohistochemical assessment of clinically non-functioning pituitary adenomas
}

\author{
Corresponding author: \\ Borys M. Kwinta MD, PhD \\ Department of Neurosurgery \\ and Neurotraumatology \\ Jagiellonian University \\ Medical College \\ Botaniczna 3 St., 31-503 Kraków, \\ Poland \\ Tel.: + 48124248662 \\ E-mail: bmkwinta@gmail.com
}

Medical Research Journal 2017; Volume 2, Number 4, 147-151 10.5603/MRJ.2017.0020 Copyright (C) 2017 Via Medica ISSN 2451-2591

\begin{abstract}
Introduction. Immunohistochemical staining is currently the gold standard of diagnostic and classification of pituitary adenomas. However, there are some discrepancies between immunohistochemical staining results and the clinical picture of pituitary adenomas. Pituitary adenomas with positive immunohistochemical reaction might not cause any endocrinological symptoms or changes in serum pituitary hormone levels. Such a discordance may be caused partly by clinically non-functioning pituitary adenomas (CNFPAs). The aim of our study was to establish the frequency of CNFPAs and identify their histological types using quantitative immunohistochemical assessment.

Materials and methods. We enrolled in the study 72 patients with pituitary adenoma, and their medical history was evaluated retrospectively. The immunohistochemical panel of anterior pituitary hormones was introduced in all cases. The immunoreactivity index was calculated manually for each specimen.

Results. $36.1 \%$ patients of the evaluated group presented as CNFPAs. Among the CNFPA patients we found $38.46 \%$ cases with positive immunohistochemical reaction for one or more anterior pituitary lobe hormones. In $23.07 \%$ of cases the adenomas were monohormonal, and in $15.38 \%$ they were plurihormonal. Conclusions. The morphometric method utilising the immunoexpression index introduced in this study provided a very precise recognition of pituitary adenoma pathology. In the case of CNFPAs the immunohistochemical staining often reveals a positive reaction also for multiple pituitary hormones. Quantitative assessment limits the subjectivity of the examiner and allows objective results comparison, so it should become a standard in histopathological assessment of pituitary adenomas.

Key words: non-functioning pituitary adenoma, immunoreactivity index, quantitative evaluation, immunohistochemical staining
\end{abstract}

Med Res J 2017; 2 (4): 147-151

\section{Introduction}

Pituitary adenomas are benign neoplasms arising from anterior pituitary secretory cells [1]. They constitute $10-20 \%$ of all intracranial neoplasms treated surgically and are the most common neoplastic lesion in the sellar region [2-4].

Due to their secretory activity, pituitary adenomas are divided into functioning and non-functioning types. Functioning adenomas manifest signs of endocrinopathies: galactorrhoea-amenorrhea syndrome [5], acromegaly or gigantism [6], Cushing disease [7], and secondary hyperthyroidism [8]. The non-functioning type, described as clinically non-functioning pituitary adenomas (CNFPAs), have no secretory activity and manifest when reaching large size [9]. They produce certain neurological symptoms such as: headache, bitemporal haemianopsia, impairment of vision acuity, and eye movement abnormalities. In some cases, CNFPAs lead to hypopituitarism or stalk syndrome [4, 10-14].

Immunohistochemical staining is currently the gold standard of diagnosis and classification of pituitary adenomas [3]. However, immunohistochemical results are not always consistent with the clinical picture. Pituitary adenomas with positive immunohistochemical reaction might not cause any endocrinological symptoms or changes in serum pituitary hormones levels [15-18]. In the case of CNFPAs, inconsistency between the lack of hormone hyperexpression symptoms and positive immunohistochemical reaction may be caused by low hormone synthesis or fast decay before secretion in 
lysosomes of adenoma cells [9, 19, 20]. Another cause that should be mentioned is a disorder of hormone storage or synthesis as well as release of biologically inactive hormones [21, 22]. The aim of our study was to establish the frequency of the CNFPA and identify their histological types using quantitative immunohistochemical assessment.

\section{Materials and methods}

We enrolled to our study patients operated on in the Department of Neurosurgery and Neurotraumatology of Jagiellonian University Medical College in Krakow and diagnosed in the Department of Neuropathology. The final study group consisted of 72 patients with complete clinical, histopathological, and radiological documentation. Demographic characteristics of study group are presented in Table 1. We collected patients' detailed medical records including medical history, neurological condition, co-morbidities, current medications, results of neurological and general examination, and, in particular, endocrinological symptoms and details about surgical procedures. Patients' endocrinological diagnoses are presented in Figure 1. All patients had full immunohistochemical panel for anterior pituitary lobe hormones: prolactin (PRL), growth hormone $(\mathrm{GH})$, adrenocorticotropic hormone (ACTH), thyroid-stimulating hormone (TSH), luteinising hormone ( $\mathrm{LH})$, follicle stimulating hormone (FSH), and alpha-subunit ( $\alpha$-SU). We compared every specimen with stained specimens from control autopsy samples to confirm that they were stained properly. A short specification of each hormone staining is presented in Table 2.

We examined all sections using a light microscope (Nikon Optishot-2) under magnification of 200x and 400x. We ruled out all parts of specimens without adenoma tissue, where we found pituitary tissue, fibrosis, haemorrhage, etc. We proceeded to morphometric analysis if at least one visual field under 200x magnification included adenoma tissue without mechanical or thermic damage and massive necrotic or haemorrhagic lesions. If we were unable to assess the specimen, we collected another sample and repeated staining.

To assess hormonal expression we used cell indexes; under 400x magnification we calculated the percentage of cells with positive immunohistochemical reaction. To perform morphometric analysis we used a morphometric grid (Fig. 2) consisting of 16 areas with equal surfaces. In each area we calculated the number of positively stained cells and number of all visible cells.

Table 1. Demographic characteristic

\begin{tabular}{llccccc}
\hline Gender & $\mathbf{n}$ & $\%$ & \multicolumn{4}{c}{ Age (years) } \\
\cline { 4 - 7 } & & & Average & SD & Min & Max \\
\hline Female & 44 & 61.11 & 45.1 & 19.1 & 10 & 84 \\
Male & 28 & 38.89 & 49.9 & 16.7 & 23 & 75 \\
Together & 72 & 100.00 & 46.9 & 18.2 & 10 & 84 \\
\hline
\end{tabular}

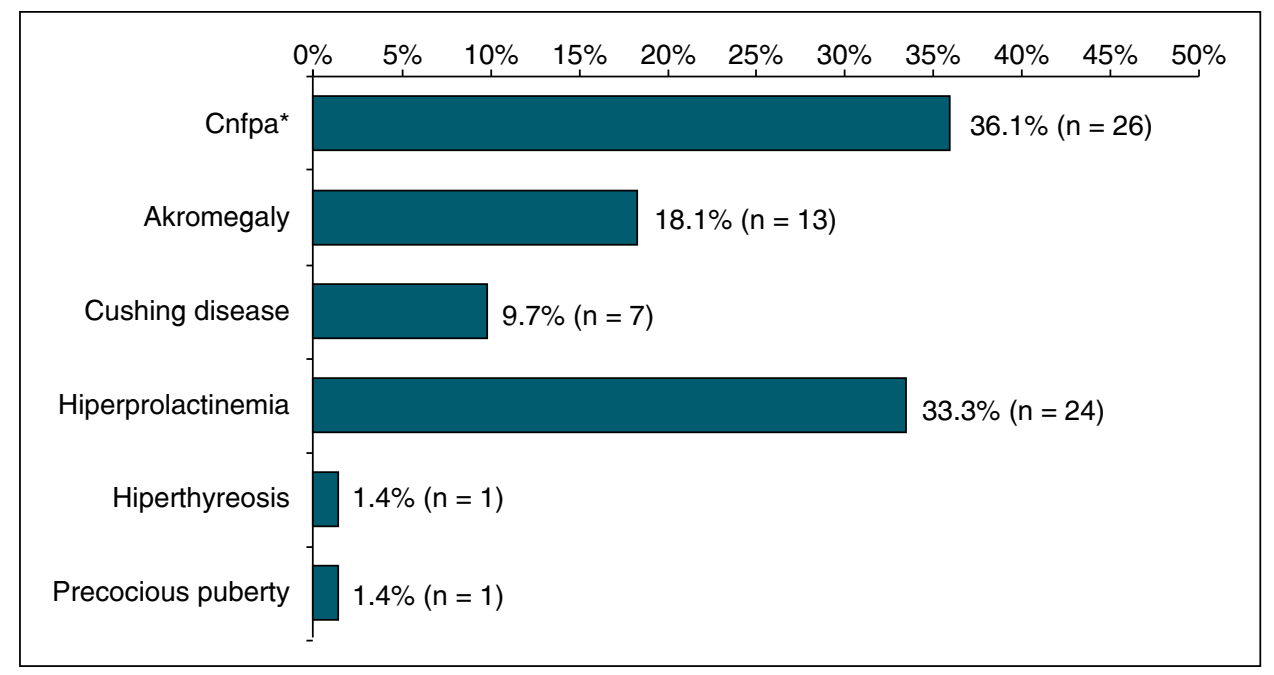

Figure 1. Endocrinological diagnoses. CNFPAs - clinically non-functioning pituitary adenomas 
Table 2. Methods of immunohistochemical staining

\begin{tabular}{|c|c|c|c|c|c|}
\hline Antibody & Producer & Dilution & Incubation time & $\begin{array}{l}\text { Visualisation } \\
\text { of reaction }\end{array}$ & Comments \\
\hline Anti-PRL & $\begin{array}{l}\text { Dako, } \\
\text { Denmark }\end{array}$ & $\begin{array}{l}\text { Ready } \\
\text { to use }\end{array}$ & $\begin{array}{l}15 \text { minutes, room } \\
\text { temperature }\end{array}$ & $\begin{array}{l}\text { EnVISION TM+ System Labelled } \\
\text { Polymer HRP-ant rabbit }\end{array}$ & \\
\hline Anti-GH & $\begin{array}{l}\text { Dako, } \\
\text { Denmark }\end{array}$ & $\begin{array}{l}\text { Ready } \\
\text { to use }\end{array}$ & $\begin{array}{l}15 \text { minutes, room } \\
\text { temperature }\end{array}$ & $\begin{array}{l}\text { EnVISION TM+ System Labelled } \\
\text { Polymer HRP-anti-rabbit }\end{array}$ & \\
\hline Anti-ACTH & $\begin{array}{l}\text { Dako, } \\
\text { Denmark }\end{array}$ & $\begin{array}{l}\text { Ready } \\
\text { to use }\end{array}$ & $\begin{array}{l}15 \text { minutes, room } \\
\text { temperature }\end{array}$ & $\begin{array}{c}\text { EnVISION TM+ System Labelled } \\
\text { Polymer HRP-anti-rabbit }\end{array}$ & \\
\hline Anti-TSH & $\begin{array}{l}\text { Novocastra, } \\
\text { Great Britain }\end{array}$ & 01:25 & $24 \mathrm{~h} 4^{\circ} \mathrm{C}$ & ABC KIT Vectastain Universal & $\begin{array}{c}\text { Antigen unmasking by } 2 \times 5 \\
\min \text { in } \mathrm{pH}=6.0 \text { buffer }\end{array}$ \\
\hline $\begin{array}{l}\text { Anti-LH } \\
\text { Anti-FSH }\end{array}$ & $\begin{array}{l}\text { Dako, } \\
\text { Denmark }\end{array}$ & $01: 25$ & $\begin{array}{l}30 \text { minutes, room } \\
\text { temperature }\end{array}$ & $\begin{array}{l}\text { EnVISION TM+ System Labelled } \\
\text { Polymer HRP-ant mouse }\end{array}$ & $\begin{array}{c}\text { Antigen unmasking by } 2 \times 5 \\
\text { min in } \mathrm{pH}=6.0 \text { buffer }\end{array}$ \\
\hline Anti- $\alpha$-SU & $\begin{array}{l}\text { Novocastra, } \\
\text { Great Britain }\end{array}$ & 0,100 & $24 \mathrm{~h} 4^{\circ} \mathrm{C}$ & ABC KIT Vectastain Universal & $\begin{array}{l}\text { Antigen unmasking by } 2 \times 5 \\
\text { min in } \mathrm{pH}=6.0 \text { buffer }\end{array}$ \\
\hline
\end{tabular}

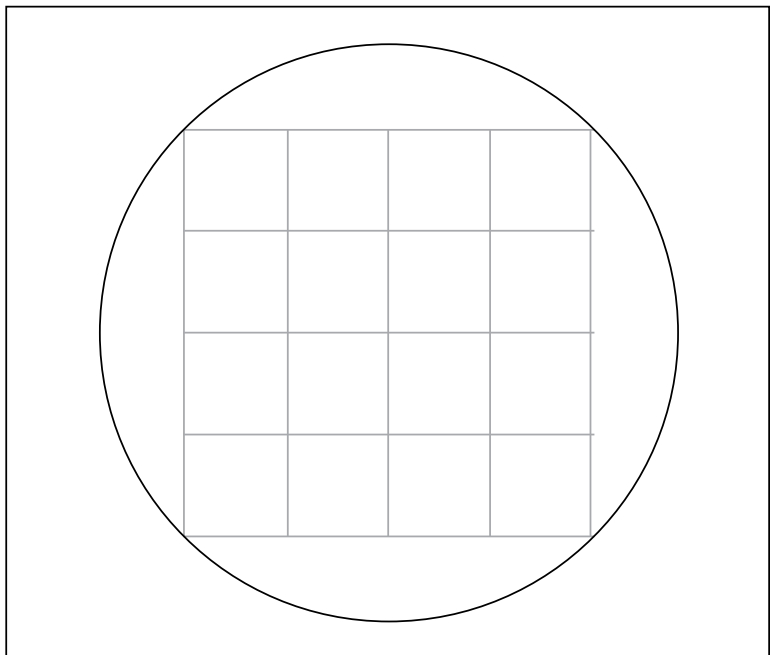

Figure 2. Morphometric grid

The small number of the $\mathrm{IHCH}$-positive cells on circuit of adenoma were recognised as "trapped" proper cells of adenohypophysis and was not counted. For each haematoxylin and eosin stained specimen we calculated the surface area. This analysis was performed for five reliable parts of each specimen.

This study was conducted in accordance with the ethical standards laid down in the Declaration of Helsinki (1964) and its design was approved by the local University Ethical Committee (protocol number $\mathrm{KBET} / 157 / \mathrm{B} / 2012)$.

\section{Results}

Final study group consisted of 72 patients between 10 and 84 years of age (mean age was 46.9 years);
$44(61.11 \%)$ of them were females. We examined a total of 504 specimens in light microscope for assessment of tropic hormones and $\alpha$-SU. Eighty-four of them were considered as positive. Immunohistochemical reactions were positive for 43 patients. We diagnosed 22 monohormonal adenomas (30.56\%), 21 plurihormonal adenomas (29.17\%), and 21 hormonally negative adenomas (29.17\%). We were unable to interpret immunohistochemical reactions in eight cases (11.11\%), and we considered them as unreliable. Among the 26 cases with CNFPA, we found negative immunohistochemical reaction in 14 (53.85\%). In 10 (38.46\%) cases we found positive immunohistochemical reaction for anterior pituitary lobe hormones - six of them were monohormonal, and four were plurihormonal. Two patients had unreliable reactions. The number and type of positive reactions among patients with CNFPA are presented in Table 3. The exact profiles of plurihormonal adenomas are listed in Table 4.

Table 3. Positive immunohistochemical reactions among patients with CNFPAs

\begin{tabular}{lcc}
\hline Reactions & Count & $\begin{array}{c}\text { Percentage } \\
\text { immunoexpression }\end{array}$ \\
\hline Anti-PRL & 0 & - \\
Anti-GH & 0 & - \\
Anti-ACTH & 2 & $16.9 \%, 41.3 \%$ \\
Anti-TSH & 1 & $12 \%$ \\
Anti-LH & 3 & $15.4 \%, 34.6 \%, 44 \%$ \\
Anti-FSH & 3 & $19.1 \%, 52.3 \%, 69.7 \%$ \\
Anti- $\alpha$-SU & 6 & $14.6 \%, 17.9 \%, 27.1 \%, 44.1 \%$, \\
Together/average & 15 & $44.6 \%, 70 \%$ \\
\hline
\end{tabular}


Table 4. Plurihormonal adenomas among the CNFPAs

\begin{tabular}{|c|c|c|c|c|c|c|}
\hline Anti-PRL & Anti-GH & Anti-ACTH & Anti-TSH & Anti-FSH & Anti-LH & Anti- $\alpha-\mathbf{S U}$ \\
\hline- & $17 \%$ & $8 \%$ & - & $53 \%$ & - & $24 \%$ \\
\hline- & - & - & - & $52.3 \%$ & $44.9 \%$ & $41.1 \%$ \\
\hline- & - & - & - & - & $15.4 \%$ & $44.6 \%$ \\
\hline- & - & - & $7.1 \%$ & - & - & $87.5 \%$ \\
\hline
\end{tabular}

\section{Discussion}

The distinction of the CNFPA is crucial for differential diagnosis. Lack of secretory activity means that clinical manifestation of the CNFPA is mainly connected with neurological symptoms of mass effect, similarly to other tumours in sellar and parasellar location (meningioma, craniopharyngioma) [23, 24].

The CFNPAs constituted $36.11 \%$ of the entire material. Their frequency in literature varies between 25 and $30 \%[9,22]$. Knosp et al. in their research established it as $46 \%$ [25]. Among the CNFPAs $38.46 \%$ had positive immunohistochemical reactions. Occurrence of the CFNPAs with positive reaction is very diverse in literature and varies between $21.2 \%$ and $87 \%$ [14, 22, 26]. In Knosp et al.'s research it was established as $15.78 \%$ [27]. This is partially explained by the electron microscopy study, which showed the existence of secretory grains in CFNPAs cells [28].

The fact that the immunohistochemically positive adenomas do not reflect clinical image can be explain by several different theories. Adenomas can secrete hormones in a concentration that is not high enough to cause a clinical effect [13]. Also, the produced hormone might be biologically inactive or might decay in lysosomes [28].

Most of the CNFPAs produce gonadotropins or glycoprotein hormone subunits [22]. We found six positive reactions for gonadotropins and six positive reactions for $\alpha$-SU.

The CNFPAs are a heterogeneous group consisting of null cell adenomas, oncocytic adenomas, silent somatotroph adenomas, silent corticotroph adenomas, silent thyrotroph adenomas, and silent gonadotroph adenomas [9]. Elevated $\mathrm{LH}$ and FSH serum levels are present in $25 \%$ of the CFNPAs, but do not correlate with $\mathrm{LH}$ and $\mathrm{FSH}$ immunoexpression [14]. In our research we found no changes in serum level of gonadotropins in patients with CNFPAs.

Among the CNFPAs with positive reactions we found four cases of plurihormonal adenomas. Those results are also consistent with a lack of correlation between clinical image and neuropathological assessment. Adenomas with expression of more than one hormone can be clinically silent [2, 29].
All of the hormonally negative adenomas were macroadenomas, which is consistent with other researchers' studies. Saeger et al. found that $95-100 \%$ of the CNFPAs are macroadenomas, and most of them show no hormonal expression in immunohistochemical examinations [14]. That phenomenon is probably caused by the fact that those tumours were able to grow silently until they caused visual symptoms [24].

The lack of full consistency between clinical and immunohistochemical images mostly concerns the CNFPAs, plurihormonal adenomas, and unreliable specimens. The CNFPAs qualified to a surgical treatment are usually large tumours with suprasellar growth. Morphometric immunohistochemical assessment with immunoreactivity index allows very accurate assessment of the CNFPAs hormonal expression. Those methods limit the subjectivity of the examiner and allow objective comparison of results; therefore, it should become a standard in histopathological assessment of pituitary adenomas.

\section{Conflict of interest: None declared.}

\section{References}

1. Lloyd RV, Kovacs K, Young Jr. Pituitary tumors: Introduction. In: Delellis RA, Lloyd RV, Heitz PU, Eng C. ed. World Health Organisation Classification of Tumours: Pathology \& Genetics - Tumours of Endocrine Organs. IARC Press, Lyon 2004: 10-13.

2. Faglia G. Epidemiology and pathogenesis of pituitary adenomas. Acta Endocrinol. 1993; 129(Suppl 1): 1-5.

3. Kontogeorgos G. Classification and pathology of pituitary tumors. Endocrine. 2005; 28(1): 27-35, doi: 10.1385/ENDO:28:1:027, indexed in Pubmed: 16311407

4. Korali Z, Müller A, Schopohl J. Hypophysentumoren und Kraniopharyngeome. . In: Manual - Hirntumoren und primäre Tumoren des Rückenmarks. Tumorzentrum München, München 2001: 89-108.

5. Scheithauer B, Kovacs K, Horvath E, et al. Pathology of the pituitary and Sellar Region. Practical Surgical Neuropathology. 2010: 371-416, doi: 10.1016/b978-0-443-06982-6.00018-3.

6. Kontogeorgos G, Watson Jr, Lindell EP. Growth hormone producing adenoma. . In: Delellis RA, Lloyd RV, Heitz PU, Eng C. ed. World Health Organisation Classification of Tumours: Pathology \& Genetics - Tumours of Endocrine Organs. IARC Press, Lyon 2004: 14-19.

7. Trouillas J, Barkan AL, Watson JRE. ACTH producing adenoma. . In: Delellis RA, Lloyd RV, Heitz PU, Eng C. ed. World Health Organisation Classification of Tumours: Pathology \& Genetics - Tumours of Endocrine Organs. IARC Press, Lyon 2004: 25-29.

8. Osamura RY, Sano T, Ezzat S. TSH producing adenoma. . In: Delellis RA, Lloyd RV, Heitz PU, Eng C. ed. World Health Organisation Classification of Tumours: Pathology \& Genetics - Tumours of Endocrine Organs. IARC Press, Lyon 2004: 24-25. 
9. Yamada S, Ohyama K, Taguchi M, et al. A study of the correlation between morphological findings and biological activities in clinically nonfunctioning pituitary adenomas. Neurosurgery. 2007; 61(3): 580-4; discussion 584, doi: 10.1227/01.NEU.0000290906.53685.79, indexed in Pubmed: 17881972.

10. Arafah BM, Prunty D, Ybarra J, et al. The dominant role of increased intrasellar pressure in the pathogenesis of hypopituitarism, hyperprolactinemia, and headaches in patients with pituitary adenomas. J Clin Endocrinol Metab. 2000; 85(5): 1789-1793, doi: 10.1210/jcem.85.5.6611, indexed in Pubmed: 10843153.

11. Gondim JA, Tella OI, Schops M. Intrasellar pressure and tumor volume in pituitary tumor: relation study. Arq Neuropsiquiatr. 2006; 64(4): 971-975, indexed in Pubmed: 17221006.

12. Levy MJ, Matharu MS, Meeran K, et al. The clinical characteristics of headache in patients with pituitary tumours. Brain. 2005; 128(Pt 8): 1921-1930, doi: 10.1093/brain/awh525, indexed in Pubmed: 15888539

13. Mahta A, Haghpanah V, Lashkari A, et al. Non-functioning pituitary adenoma: immunohistochemical analysis of 85 cases. Folia Neuropathol. 2007; 45(2): 72-77, indexed in Pubmed: 17594597.

14. Saeger W, Lüdecke DK, Buchfelder M, et al. Pathohistological classification of pituitary tumors: 10 years of experience with the German Pituitary Tumor Registry. Eur J Endocrinol. 2007; 156(2): 203-216, doi 10.1530/eje 1.02326, indexed in Pubmed: 17287410

15. Fahlbusch R, Buslei R. The WHO classification of pituitary tumours: a combined neurosurgical and neuropathological view. Acta Neuropathol. 2006; 111(1): 86-87, doi: 10.1007/s00401-005-1106-5, indexed in Pubmed: 16311771

16. Hamid Z, Mrak R, ljaz M, et al. Sensitivity and specificity of immunohistochemistry in pituitary adenomas. The Endocrinologist. 2009; 19(1): 38-43, doi: 10.1097/ten.0b013e31819390ce.

17. Ho DM, Hsu CY, Ting LT, et al. Plurihormonal pituitary adenomas: immunostaining of all pituitary hormones is mandatory for correct classification. Histopathology. 2001; 39(3): 310-319, indexed in Pubmed: 11532042

18. Sung-Ku P, Shin J, Tae-Young J, et al. Correlation of clinical and immunohistochemical diagnosis in patients with pituitary adenomas. Korean Neurosurg Soc. 2007; 41: 367-370.
19. Herzog T, Schlote W, Lorenz R, et al. Pituitary adenomas: serum hormone levels and immunohistochemical staining for ACTH, GH and prolactin. Clin Neuropathol. 1993; 12(2): 117-120, indexed in Pubmed: 8386600

20. Pawlikowski M, Kunert-Radek J, Radek M. Plurihormonality of pituitary adenomas in light of immunohistochemical studies. Endokrynol Pol. 2010; 61(1): 63-66, indexed in Pubmed: 20205106.

21. Sen O, Ertorer ME, Aydin MV, et al. Silent pituitary macroadenoma co-secreting growth hormone and thyroid stimulating hormone. J Clin Neurosci. 2005; 12(3): 318-320, doi: 10.1016/j.jocn.2004.05.011, indexed in Pubmed: 15851094

22. Zhao D, Tomono $Y$, Tsuboi $K$, et al. Immunohistochemical and ultrastructural study of clinically nonfunctioning pituitary adenomas. Neurol Med Chir (Tokyo). 2000; 40(9): 453-6; discussion 456, indexed in Pubmed: 11021076

23. Destrieux C, Kakou MK, Velut S, et al. Microanatomy of the hypophyseal fossa boundaries. J Neurosurg. 1998; 88(4): 743-752, doi: 10.3171/jns.1998.88.4.0743, indexed in Pubmed: 9525722.

24. DI CHIRO G, NELSON KB. The volume of the sella turcica. Am J Roentgenol Radium Ther Nucl Med. 1962; 87: 989-1008, indexed in Pubmed: 13885978

25. Knosp E, Krisch K, Schmidbauer M, et al. Immunologischer Hormonnachweis bei Hypophysenadenomen: Korrelation von Serumhormonbefunden mit immunzytochemischem Hormonbefund am Tumorschnitt. Wien Klin Wochenschr. 1988; 100: 322-325.

26. Asa SL, Ezzat S, Watson JRE. Gonadotropin producing adenoma. I. In: Delellis RA, Lloyd RV, Heitz PU, Eng C. ed. World Health Organisation Classification of Tumours: Pathology \& Genetics - Tumours of Endocrine Organs. IARC Press, Lyon 2004: 30-32

27. Gsponer J, De Tribolet N, Déruaz JP, et al. Diagnosis, treatment, and outcome of pituitary tumors and other abnormal intrasellar masses. Retrospective analysis of 353 patients. Medicine (Baltimore). 1999; 78(4): 236-269, indexed in Pubmed: 10424206.

28. Maksymowicz M. Ocena przydatności mikroskopii elektronowej i immunocytochemii na poziomie ultrastrukturalnym w diagnostyce klasyfikac gruczolaków przysadki [dissertation]. Medical University of Warsaw, 2005

29. Bieniecki W, Sekulska J. Segmentacja i analiza obrazów mikroskopowyc barwionych immunohistochemicznie. Automatyka. 2003; 7: 283-293. 